\title{
Screening Cover Crops for Use in Conservation Tillage Systems for Vegetables Following Spring Plowing
}

\author{
Wendy A. Nelson', Brian A. Kahn ${ }^{2}$, and B. Warren Roberts ${ }^{3}$ \\ Department of Horticulture and Landscape Architecture, Oklahoma State \\ University, Stillwater, OK 74078-0511
}

Additional index words. groundcovers, grasses, legumes, low-till, minimum-till

Abstract. Several prospective cover crops were sown into $1-\mathrm{m}^{2}$ monoculture plots on 9 Mar. 1987 and 10 Mar. 1988 at Bixby, Okla., and on 14 Mar. 1988 at Lane, Okla., after sites were plowed and fitted. Densities and dry weights of cover crops and weeds were determined in late April or early May of both years. Plots also were evaluated for degree of kill by glyphosate in $\mathbf{1 9 8 8}$. Fourteen cover crops were screened at Bixby in 1987. Kentucky bluegrass (Poa pratensis L.) and three fescues (Festuca rubra L., Festuca rubra L. var. commutata Gaud.-Beaup., and Festuca elatior L.) were eliminated from further consideration due to inadequate cover density and inability to suppress weeds. Screenings of the 10 remaining covers were conducted at both locations in 1988 . Annual ryegrass (Lolium multiflorum L.) and three small grains [rye (Secale cereale L.), barley (Hordeum vulgare L.), and wheat (Triticum aestivum L.)] were the most promising cover crops with respect to cover density, competitiveness against weeds, and degree of kill by glyphosate. Crimson clover (Trifolium incarnatum L.) and hairy vetch (Vicia villosa Roth) were the most promising legumes, but they generally were less satisfactory than the grassy covers in all tested aspects. A single application of glyphosate was ineffective in killing hairy vetch at both locations. Chemical name used: $\mathbf{N}$-(phosphonomethyl)glycine (glyphosate).

Interest in conservation tillage for crop production has developed in response to concerns over soil erosion. The principles and benefits of conservation tillage have been reviewed (Allmaras and Dowdy, 1985; Phillips et al., 1980; Unger and McCalla, 1980). Many experiments have been conducted on conservation tillage for field crops, and an extensive literature base has been formed. Fewer studies have been conducted on conservation tillage for vegetable crops. A review of these studies led to two conclusions. First, reduced tillage was more promising than no tillage as a strategy for production of several vegetables (Beste, 1983; Doss et al., 1981; Knavel and Herron, 1981; Robinson, 1985). Second, "living mulches" (Hughes and Sweet, 1979) usually

Received for publication 18 June 1990. Journal Article no. J-5810 of the Agr. Expt. Sta., Oklahoma State Univ., Stillwater. We gratefully acknowledge the donation of inoculants by R. Stewart Smith, The Nitragin Company, Milwaukee. The information given in this publication is for educational purposes only. Mention of a trademark, proprietary product, or vendor does not constitute a guarantee or warranty of the product, nor does it imply approval or disapproval to the exclusion of other products or vendors that may also be available. The cost of publishing this paper was defrayed in part by the payment of page charges. Under postal regulations, this paper therefore must be hereby marked advertisement solely to indicate this fact.

'Former Graduate Assistant. Present address: R.R. 2, Box 235, Chelsea, OK 74016.

Associate Professor, to whom reprint requests should be addressed.

Assistant Professor, Wes Watkins Agricultural Research and Extension Center, P.O. Box 128, Lane, OK 74555 have proven to be excessively competitive with interplanted vegetable crops (Altieri et al., 1985; Nicholson and Wien, 1983).

The present study marked the beginning of an effort to develop a conservation tillage system for warm-season vegetable production that did not exclude some tillage and that used killed cover crops. The objective of the present study was to identify one or more cover crops that would establish quickly following spring plowing and produce a completely killed, dense, weed-free ground cover into which warm-season vegetables could be planted in mid-spring. Monoculture screenings of several prospective cover crops were conducted with respect to adaptation, density, biomass production, competitiveness with weeds, and degree of suppression obtained from a single glyphosate application.

Table 1. Cover crops and seeding rates used in monoculture screenings.

\begin{tabular}{llc}
\hline \hline Common name & \multicolumn{1}{c}{ Scientific name } & $\begin{array}{c}\text { Seeding rate } \\
\left(\mathrm{g} \cdot \mathrm{m}^{-2}\right)\end{array}$ \\
\hline Barley & Hordeum vulgare L. & 9.4 \\
Oats & Avena sativa L. & 9.9 \\
Rye & Secale cereale L. & 7.8 \\
Wheat & Triticum aestivum L. & 8.4 \\
Annual ryegrass & Lolium multiflorum L. & 3.1 \\
Chewing's fescue & Festuca rubra L. var. commutata & 3.1 \\
& Gaud.-Beaup. & 3.1 \\
Red fescue & Festuca rubra L. & 3.1 \\
Tall fescue & Festuca elatior L. & 2.2 \\
Kentucky bluegrass & Poa pratensis L. & 2.2 \\
Crimson clover & Trifolium incamatum L. & 1.1 \\
Red clover & Trifolium pratense L. & 0.7 \\
White clover & Trifolium repens L. & 6.7 \\
Austrian winter pea & Pisum sativum arvense (L.) Poir & 3.4 \\
Hairy vetch & Vicia villosa Roth &
\end{tabular}

Studies were conducted in 1987 and 1988 at the Vegetable Research Station, Bixby, Okla., on a Severe very fine sandy loam [coarse-silty, mixed (calcareous), thermic Typic Udifluvents]. A second experimental site in 1988 was the Wes Watkins Agricultural Research and Extension Center, Lane, Okla. The soil type at Lane was a Bernow fine sandy loam (fine-loamy, siliceous, thermic Glossic Paleudalf). The experimental design at both locations was a randomized complete block with four replications.

Initial soil preparation at both sites consisted of plowing and harrowing. A broadcast, preplant-incorporated application of fertilizer was made at Bixby in both years; fertilizer rates were $58 \mathrm{~N}-26 \mathrm{P}-48 \mathrm{~K}\left(\mathrm{~kg} \cdot \mathrm{ha}^{-1}\right)$ in 1987 and $60 \mathrm{~N}-27 \mathrm{P}-50 \mathrm{~K}\left(\mathrm{~kg} \cdot \mathrm{ha}^{-1}\right)$ in 1988 , respectively. No supplemental fertilization was used at Lane, and no supplemental irrigation was used at either location. Rainfall during the period between seeding and plot sampling totaled $80 \mathrm{~mm}$ at Bixby in 1987, $90 \mathrm{~mm}$ at Bixby in 1988, and $100 \mathrm{~mm}$ at Lane in 1988.

The cover crops were seeded by hand into $1-\mathrm{m}^{2}$ plots using normal pasture rates (Martin et al., 1976) (Table 1). Germination tests were conducted before planting each year and the seeding rates adjusted accordingly. Seeds were weighed for each plot to ensure correct planting rates, broadcast as uniformly as possible, and incorporated with a light bowraking, with the exception of the large-seeded legumes (hairy vetch and Austrian winter pea). These two crops were sown in three shallow furrows per plot, spaced at $30 \mathrm{~cm}$ between furrows. All legume seeds were inoculated with appropriate Rhizobia. Control plots also were bow-raked. Fourteen covers were screened at Bixby in 1987 (Table 1). Kentucky bluegrass and the three fescues were eliminated following this initial study, and the remaining 10 covers were screened at both locations in 1988. Sowing dates were 9 Mar. 1987 and 10 Mar. 1988 at Bixby and 14 Mar. 1988 at Lane.

The plots were evaluated on 7 May 1987 and 25 Apr. 1988 at Bixby and on 2 May 1988 at Lane. The densities of the cover crop and weed populations were determined using the rope-knot method of Sloneker and Mol- 
Table 2. Characteristics of cover crops grown in monoculture, 1-m² plots at Bixby, Okla., 1987.

\begin{tabular}{|c|c|c|c|c|c|}
\hline \multirow[b]{2}{*}{ Cover crop } & \multicolumn{2}{|c|}{$\begin{array}{c}\text { Portion (\%) of } \\
\text { ground covered by: }\end{array}$} & \multirow[b]{2}{*}{$\begin{array}{c}\text { Bare soil } \\
(\%)\end{array}$} & \multirow[b]{2}{*}{$\begin{array}{l}\text { Dry wt weeds : } \\
\text { dry wt cover }\end{array}$} & \multirow{2}{*}{$\begin{array}{c}\text { Cover crop } \\
\text { ht } \\
(\mathrm{cm})\end{array}$} \\
\hline & $\begin{array}{l}\text { Cover } \\
\text { crop }\end{array}$ & Weeds & & & \\
\hline Control & --- & $44 \mathrm{a}$ & $56 \mathrm{a}$ & --- & $11^{y} \mathrm{~d}$ \\
\hline Barley & $83 b^{2}$ & $1 \mathrm{f}$ & $16 \mathrm{de}$ & $<0.1 \mathrm{~b}$ & 28 a \\
\hline Oats & $73 c$ & 5 def & $22 \mathrm{bcd}$ & $<0.1 \mathrm{~b}$ & $28 \mathrm{a}$ \\
\hline Rye & $93 \mathrm{a}$ & $2 \mathrm{f}$ & $5 \mathrm{f}$ & $<0.1 \mathrm{~b}$ & $30 a$ \\
\hline Wheat & $74 \mathrm{c}$ & 7 def & 19 cde & $<0.1 \mathrm{~b}$ & $20 \mathrm{bc}$ \\
\hline Annual ryegrass & $85 \mathrm{~b}$ & 4 ef & 10 ef & $<0.1 \mathrm{~b}$ & $18 c$ \\
\hline Chewing's fescue & $37 \mathrm{f}$ & $35 \mathrm{ab}$ & $28 \mathrm{bc}$ & $3.3 \mathrm{a}$ & $4 \mathrm{~g}$ \\
\hline Red fescue & $51 \mathrm{e}$ & $22 \mathrm{bc}$ & $27 \mathrm{bcd}$ & $2.7 \mathrm{a}$ & $5 \mathrm{fg}$ \\
\hline Tall fescue & $49 \mathrm{e}$ & $29 a b$ & $22 \mathrm{bcd}$ & $0.8 \mathrm{~b}$ & $8 \mathrm{e}$ \\
\hline Kentucky bluegrass & $28 \mathrm{~g}$ & 41 a & $31 \mathrm{~b}$ & 4.3 a & $3 \mathrm{~g}$ \\
\hline Crimson clover & $72 \mathrm{c}$ & $11 \mathrm{cde}$ & $17 \mathrm{cde}$ & $0.1 \mathrm{~b}$ & $12 \mathrm{~d}$ \\
\hline Red clover & $53 \mathrm{de}$ & $19 \mathrm{bc}$ & $28 \mathrm{bc}$ & $0.4 \mathrm{~b}$ & $14 \mathrm{~d}$ \\
\hline White clover & $58 \mathrm{de}$ & $24 \mathrm{bc}$ & $18 \mathrm{cde}$ & $0.8 \mathrm{~b}$ & 7 ef \\
\hline Austrian winter pea & $62 d$ & $15 \mathrm{~cd}$ & $23 \mathrm{bcd}$ & $0.1 \mathrm{~b}$ & $21 b$ \\
\hline Hairy vetch & $83 \mathrm{~b}$ & 13 cde & $4 \mathrm{f}$ & $0.1 \mathrm{~b}$ & $13 \mathrm{~d}$ \\
\hline
\end{tabular}

${ }^{2}$ Mean separation in columns by Waller-Duncan $t$ test, K ratio $=100$.

${ }^{y}$ Mean height of weeds in control plots, for comparison with cover crop heights.

Table 3. Characteristics of cover crops grown in monoculture, $1-\mathrm{m}^{2}$ plots at Bixby, Okla., 1988.

\begin{tabular}{|c|c|c|c|c|c|c|}
\hline \multirow[b]{2}{*}{ Cover crop } & \multicolumn{2}{|c|}{$\begin{array}{l}\text { Portion (\%) of } \\
\text { ground covered by: }\end{array}$} & \multirow[b]{2}{*}{$\begin{array}{c}\text { Bare soil } \\
(\%)\end{array}$} & \multirow[b]{2}{*}{$\begin{array}{l}\text { Dry wt weeds : } \\
\text { dry wt cover }\end{array}$} & \multirow{2}{*}{$\begin{array}{c}\text { Cover crop } \\
\text { ht } \\
(\mathrm{cm})\end{array}$} & \multirow{2}{*}{$\begin{array}{c}\text { Kill by } \\
\text { glyphosate } \\
(\%)\end{array}$} \\
\hline & $\begin{array}{l}\text { Cover } \\
\text { crop }\end{array}$ & Weeds & & & & \\
\hline Control & -- & 33 a & $67 \mathrm{a}$ & --- & $3^{y}$ ef & $96 \mathrm{a}$ \\
\hline Barley & $73 a b^{2}$ & $8 \mathrm{e}$ & 19 ef & $<0.1 \mathrm{c}$ & $9 \mathrm{~b}$ & $100 \mathrm{a}$ \\
\hline Oats & 43 ef & 12 cde & $45 \mathrm{~b}$ & $<0.1 \mathrm{c}$ & $6 \mathrm{~d}$ & $100 \mathrm{a}$ \\
\hline Rye & $65 \mathrm{bc}$ & $8 \mathrm{e}$ & $27 \mathrm{de}$ & $<0.1 \mathrm{c}$ & $10 \mathrm{ab}$ & $100 \mathrm{a}$ \\
\hline Wheat & $61 \mathrm{bcd}$ & $12 \mathrm{cde}$ & $27 \mathrm{de}$ & $<0.1 \mathrm{c}$ & $7 \mathrm{~cd}$ & $100 \mathrm{a}$ \\
\hline Annual ryegrass & $78 \mathrm{a}$ & $10 \mathrm{de}$ & $12 \mathrm{f}$ & $<0.1 \mathrm{c}$ & $11 \mathrm{a}$ & $98 \mathrm{a}$ \\
\hline Crimson clover & $62 b c$ & 12 cde & $26 \mathrm{de}$ & $<0.1 \mathrm{c}$ & $5 \mathrm{~d}$ & $71 \mathrm{~b}$ \\
\hline Red clover & $53 \mathrm{cde}$ & $21 b c$ & $26 \mathrm{de}$ & $0.2 b c$ & $6 \mathrm{~d}$ & $63 \mathrm{bc}$ \\
\hline White clover & $39 \mathrm{f}$ & $20 \mathrm{bcd}$ & $41 \mathrm{bc}$ & $0.4 \mathrm{a}$ & $4 \mathrm{e}$ & $56 \mathrm{c}$ \\
\hline Austrian winter pea & 49 def & 16 bcde & $35 \mathrm{~cd}$ & $0.3 \mathrm{ab}$ & $8 \mathrm{c}$ & $61 \mathrm{bc}$ \\
\hline Hairy vetch & 46 ef & $23 \mathrm{ab}$ & $31 \mathrm{~d}$ & $0.2 \mathrm{bc}$ & $2 \mathrm{f}$ & $9 \mathrm{~d}$ \\
\hline
\end{tabular}

${ }^{2}$ Mean separation in columns by Waller-Duncan $t$ test, $\mathrm{K}$ ratio $=100$.

yMean height of weeds in control plots, for comparison with cover crop heights.

Table 4. Characteristics of cover crops grown in monoculture, 1-m² plots at Lane. Okla.. 1988.

\begin{tabular}{|c|c|c|c|c|c|c|}
\hline \multirow[b]{2}{*}{ Cover crop } & \multicolumn{2}{|c|}{$\begin{array}{l}\text { Portion (\%) of } \\
\text { ground covered by: }\end{array}$} & \multirow[b]{2}{*}{$\begin{array}{c}\text { Bare soil } \\
(\%)\end{array}$} & \multirow[b]{2}{*}{$\begin{array}{l}\text { Dry wt weeds : } \\
\text { dry wt cover }\end{array}$} & \multirow{2}{*}{$\begin{array}{c}\text { Cover crop } \\
\text { ht } \\
\text { (cm) }\end{array}$} & \multirow{2}{*}{$\begin{array}{l}\text { Kill by } \\
\text { glyphosate } \\
(\%)\end{array}$} \\
\hline & $\begin{array}{l}\text { Cover } \\
\text { crop }\end{array}$ & Weeds & & & & \\
\hline Control & $\ldots$ & $54 \mathrm{a}$ & $46 \mathrm{a}$ & $\cdots$ & $7^{y} b c$ & $64 \mathrm{a}$ \\
\hline Barley & $46 c^{2}$ & $30 \mathrm{~cd}$ & 24 bcd & $0.7 \mathrm{c}$ & $8 b$ & $71 \mathrm{a}$ \\
\hline Oats & $60 \mathrm{~b}$ & $17 \mathrm{de}$ & $23 \mathrm{~cd}$ & $0.3 \mathrm{c}$ & $14 \mathrm{a}$ & $52 \mathrm{ab}$ \\
\hline Rye & 83 a & $7 \mathrm{e}$ & $10 \mathrm{e}$ & $0.1 \mathrm{c}$ & $13 \mathrm{a}$ & $68 \mathrm{a}$ \\
\hline Wheat & $47 \mathrm{c}$ & $31 \mathrm{~cd}$ & $22 \mathrm{cde}$ & $0.2 \mathrm{c}$ & 7 bc & $69 \mathrm{a}$ \\
\hline Annual ryegrass & $70 \mathrm{~b}$ & $17 \mathrm{de}$ & $13 \mathrm{de}$ & $0.1 \mathrm{c}$ & $10 \mathrm{ab}$ & $35 \mathrm{bc}$ \\
\hline Crimson clover & $18 \mathrm{de}$ & $47 a b c$ & $35 \mathrm{abc}$ & $4.6 \mathrm{c}$ & $3 \mathrm{~cd}$ & $21 \mathrm{~cd}$ \\
\hline Red clover & $14 \mathrm{e}$ & $49 a b$ & $37 \mathrm{abc}$ & $13.1 \mathrm{~b}$ & $4 \mathrm{~cd}$ & $15 \mathrm{~cd}$ \\
\hline White clover & $11 \mathrm{e}$ & $53 \mathrm{a}$ & $36 a b c$ & $23.2 \mathrm{a}$ & $2 d$ & $9 \mathrm{de}$ \\
\hline Austrian winter pea & $10 \mathrm{e}$ & $50 \mathrm{ab}$ & $40 \mathrm{a}$ & $13.3 \mathrm{~b}$ & 6 bcd & $48 \mathrm{ab}$ \\
\hline Hairy vetch & $25 \mathrm{~d}$ & $36 \mathrm{bc}$ & $39 \mathrm{ab}$ & $2.4 \mathrm{c}$ & $3 \mathrm{~cd}$ & $1 \mathrm{c}$ \\
\hline
\end{tabular}

${ }^{2}$ Mean separation in columns by Wailer-Duncan $t$ test, $\mathrm{K}$ ratio $=100$.

${ }^{y}$ Mean height of weeds in control plots, for comparison with cover crop heights.

denhauer (1977) as adapted by Nicholson and Wien (1983). Cover crop heights also were measured (three readings per plot, which were averaged). Following these evaluations, plots were sampled using a $50 \times 50-\mathrm{cm}$ square. All plants within the boundaries of the square were cut by hand at soil level, separated into weeds and cover crops, dried at 55C for at least 3 days, and weighed. Sampling oc- $\mathrm{kg} \cdot \mathrm{ha}^{-1}$, with a water carrier, a spray volume of 262 liters'ha ${ }^{-1}$, and no adjuvants. The rate at Lane was higher $\left(2.2 \mathrm{~kg} \cdot \mathrm{ha}^{-1}\right)$ due to greater weed pressure. The Lane treatment involved a water carrier, a spray volume of 98 liters $\cdot \mathrm{ha}^{-1}$ and a spreader added at $0.25 \% \mathrm{v} / \mathrm{v}(\mathrm{X}-77$; Valent USA, Walnut Creek, Calif.). There was no rainfall within $24 \mathrm{~h}$ of application at either site. Visual estimations of percent kill of the cover crops were made 18 and 24 days after treatment at Bixby and Lane, respectively, by two persons working independently and were averaged. Glyphosate generally killed most of the weeds present in the plots, especially at Bixby.

Data were evaluated with an analysis of variance. Mean separations were performed using the Waller-Duncan $\mathrm{t}$ test with a $\mathrm{K}$ ratio equal to 100 .

Bixby, 1987. The greatest percentage of ground cover was produced by rye (Table 2). Relatively high cover crop densities also were produced by barley, wheat, oats, annual ryegrass, hairy vetch, and crimson clover (Table 2). The four small grains and annual ryegrass also provided a high degree of weed suppression, with three of the four turfgrasses (Chewing's fescue, tall fescue, and Kentucky bluegrass) not significantly different from the weedy control. All covers reduced the amount of bare soil compared to the weedy control, with only $5 \%$ and $4 \%$ bare soil remaining in the rye and hairy vetch plots, respectively (Table 2). Kentucky bluegrass, Chewing's fescue, and red fescue all produced weed : cover dry weight ratios $>1.0$, while the four small grains and annual ryegrass all produced ratios $<0.1$. Rye, oats, and barley were taller than the other crops, with the four turfgrasses and white clover producing the least amount of vertical growth (Table 2). At the conclusion of this study, the four turfgrasses were eliminated from further consideration due to poor establishment of ground cover and inadequate competition against weeds.

Bixby, 1988. The general tendencies observed in 1987 were reinforced by the screening of the remaining 10 crops in 1988 . Grassy covers tended to perform better than leguminous crops. Annual ryegrass produced a higher percentage of ground cover than any other crop, except barley (Table 3). However, due to bird damage, the percentages of ground cover resulting from growth of the small grains were somewhat lower than those observed in 1988, with oats suffering the greatest reduction. Barley and rye plots contained only $8 \%$ ground cover due to weeds, but did not differ significantly in weed suppression from oats, wheat, annual ryegrass, crimson clover, and Austrian winter pea. Hairy vetch was not significantly different from the weedy control in weed density, in contrast to the result from 1987. All covers reduced the amount of bare soil compared to the weedy control, as in 1987, with annual ryegrass plots containing less exposed soil than plots of any other cover, except barley (Table 3). All crops produced weed : cover dry weight ratios $<1.0$, with 
six of the 10 crops having ratios $<0.1$. The tallest crops were annual ryegrass, rye, and barley, while white clover and hairy vetch were the shortest crops screened. The five grassy crops exhibited at least $98 \%$ kill by glyphosate, in general agreement with the findings of Weston (1990). The legumes were intermediate in the degree to which they were killed, except for hairy vetch, which was tolerant to the herbicide (Table 3 ).

Lane, 1988. There was some unexplained difficulty with legume stand establishment at Lane. Consequently, the four small grains and annual ryegrass produced the greatest percentages of ground cover (Table 4). Rye was particularly suppressive to weed establishment (Table 4). Among the legumes, only hairy vetch gave a significant reduction in ground cover due to weeds, compared to the weedy control and in contrast to the finding at Bixby in 1988. No legume crop significantly reduced the amount of bare soil compared to the weedy control (Table 4). Weed pressure was high, and five of the cover crops produced weed : cover dry weight ratios $>1.0$. However, only three legumes (white clover, Austrian winter pea, and red clover) were significantly different from the remaining seven crops. Oats and rye were the only crops to exceed the mean height of the weeds. Glyphosate was less effective in killing the cover crops at Lane than at Bixby in 1988, despite the higher rate used at Lane. The grassy covers again proved to be easiest to kill, and hairy vetch again exhibited tolerance to the herbicide (Table 4).

Overall, rye, annual ryegrass, barley, and wheat emerged as the most promising cover crops with respect to cover density, competitive ability against weeds, and degree of kill obtained from a single application of glyphosate. These results generally agree with those of Moschler et al. (1967), except that we did not observe herbicide tolerance with barley (Moschler et al. did not use glyphosate). All four of the most promising cover crops were grasses. Weston (1990) reported that rye and wheat were superior cover crops for vegetable no-tillage systems compared to some of the same species that were screened in the present study, including tall fescue, creeping red fescue, and white clover. Crimson clover and hairy vetch were the best legumes in the present study, in agreement with the findings of Hoyt and Hargrove (1986). However, the high degree of tolerance to glyphosate exhibited by hairy vetch indicates that an alternative, effective herbicide must be found before this cover crop can be used in a killed-cover conservation till age system.

\section{Literature Cited}

Allmaras, R.R. and R.H. Dowdy. 1985. Conservation tillage systems and their adoption in the United States. Soil Tillage Res. 5:197-222.

Altieri, M.A., R.C. Wilson, and L.L. Schmidt. 1985. The effects of living mulches and weed cover on the dynamics of foliage- and soil-arthropod communities in three crop systems. Crop Protection 4(2):201-213.

Beste, C.E. 1983. No-tillage systems for vegetables and ornamental. Proc. Northeastern Weed
Sci. Soc. 37(Suppl.):52-57.

Doss, B.D., J.L. Turner, and C.E. Evans. 1981. Influence of tillage, nitrogen, and rye cover crop on growth and yield of tomatoes. J. Amer. Soc. Hort. Sci. 106:95-97.

Hoyt, G.D. and W.L. Hargrove. 1986. Legume cover crops for improving crop and soil management in the southern United States. HortScience 21:397-402.

Hughes, B.J. and R.D. Sweet. 1979. Living mulch: A preliminary report on grassy cover crops interplanted with vegetables. Proc. Northeastern Weed Sci. Soc. 33:109.

Knavel, D.E. and J.W. Herron. 1981. Influence of tillage system, plant spacing, and nitrogen on head weight, yield, and nutrient concentration of spring cabbage. J. Amer. Soc. Hort. Sci. 106:540-545.

Martin, J.H., W.H. Leonard, and D.L. Stamp. 1976. Principles of field crop production. 3rd ed. Macmillan, New York.

Moschler, W.W., G.M. Shear, D.L. Hallock, R.D. Sears, and G.D. Jones. 1967. Winter cover crops for sod-planted corn: Their selection and management. Agron. J. 59:547-551.

Nicholson, A.G. and H.C. Wien. 1983. Screening of turfgrasses and clovers for use as living mulches in sweet corn and cabbage. J. Amer. Soc. Hort. Sci. 108:1071-1076.

Phillips, R.E., R.L. Blevins, G.W. Thomas, W.W. Frye, and S.H. Phillips. 1980. No-tillage agriculture. Science 208:1108-1113.

Robinson, R.G. 1985. Tillage for sunflower control and for annual canarygrass and fieldbean production. Agron. J. 77:612-616.

Sloneker, L.L. and W.C. Moldenhauer. 1977. Measuring the amounts of crop residue remaining after tillage. J. Soil Water Conservation 32:231-236.

Unger, P.W. and T.M. McCalla. 1980. Conservation tillage systems, p. 1-58. In: N.C. Brady (ed.). Advances in agronomy. vol. 33. Academic, New York.

Weston, L.A. 1990. Cover crop and herbicide influence on row crop seedling establishment in no-tillage culture. Weed Sci. 38:166-171. 